DOI: $10.35784 /$ IAPGOS.240

\title{
AN OPTIMIZATION OF A DIGITAL CONTROLLER FOR A STOCHASTIC CONTROL SYSTEM
}

\author{
Igor Golinko ${ }^{1}$, Volodymyr Drevetskiy ${ }^{2}$ \\ ${ }^{1}$ National Technical University of Ukraine "Igor Sikorsky Kyiv Polytechnic Institute", Department of Automation of Heat and Power Engineering Processes, Kiev, Ukraine, \\ ${ }^{2}$ National University of Water Management and Nature Resources Use, Department of Automation, Electrical and Computer-Integrated Technologies, Rivne, Ukraine
}

\begin{abstract}
The article deals with the synthesis of an optimal digital controller for a stochastic plant. In order to optimize the control system, an integral quality criterion together with minimization of the controlled parameter variance that is offered here, besides the control actions the control objects are taken into account. Using the methods of optimization theory for a single-loop control system, the structure and parameters of the digital regulator are determined. The structure of the digital controller is analysed from the parameters of the quality criterion and the mathematical description of the control object. An example of the synthesis of a digital controller for an automatic control system for the air temperature at the output of the $C V$ - $P^{\circ} 2 L^{\circ} N-63 B / F-N$ ceiling conditioner, which showed the efficiency of the digital controller when compensating for random disturbances, is given here. The obtained results are recommended to be used by the specialists on automation for the control system design as well as optimization of the existing ones.
\end{abstract}

Keywords: optimization, quality criterion, digital controller, stochastic control system

\section{OPTYMALIZACJA STEROWNIKA CYFROWEGO DLA SYSTEMU REGULACJI STOCHASTYCZNEJ}

Streszczenie. Artykut dotyczy syntezy optymalnego sterownika cyfrowego dla stochastycznego obiektu kontrolnego. Aby zoptymalizować system regulacji, zaproponowano integralne kryterium jakości z minimalizacja wariancji kontrolowanego parametru, oprócz działań kontrolnych obiektów sterujących. Wykorzystując metody teorii optymalizacji dla jednopętlowego systemu sterowania, określana jest struktura i parametry sterownika cyfrowego. Strukture kontrolera cyfrowego przeanalizowano na podstawie parametrów kryterium jakości i opisu matematycznego obiektu kontrolnego. Podano przykład syntezy kontrolera cyfrowego dla automatycznego systemu kontroli temperatury powietrza na wyjściu klimatozatora $C V$ - $P^{\circ} 2 L^{\circ} N-63 B / F-N$, który pokazat wydajność cyfrowego regulatora przy kompensacji zakłóceń losowych. Uzyskane wyniki są zalecane do wykorzystania przez specjalistów w dziedzinie automatyki przy projektowaniu i optymalizacji już istniejacych systemów regulacji.

Słowa kluczowe: optymalizacja, kryterium jakości, cyfrowy kontroler, system kontroli stochastycznej

\section{Introduction}

As a rule, the work on putting automatic control systems (ACSs) of complex technological processes takes much time and has to be done by highly skilled specialists. However, we know from experience that in the majority of cases the tunings of commissioned control systems are far from being optimal, which entails certain economic losses. These losses are usually hidden ones because nobody records them as such. If we succeed in organizing automated selection of the tuning parameters, it becomes possible to achieve essentially smaller losses connected with non-optimal tuning and a shorter period of time taken to put the ACS in operation.

The requirements imposed on the performance of control systems have now become more stringent: an ACS shall ensure the required quality of control and minimize the expenditure of material and energy resources for achieving the goals that were set forth. It would seem that the stated problem can well be solved using the dynamic system optimization theory, central to which is representation of ACS models in vector-matrix form. However, the mathematical technique of vector-matrix analysis, which is quite efficient for systems with lumped parameters, in poorly adapted for analysing controlled plants with distributed parameters and/or transport time delay. In addition, the majority of Softlogictype systems for programming controllers cannot operate with variables in the form of arrays, due to which the use of vectormatrix mathematical analysis methods is impossible for such applications.

Engineers who tune ACSs of technological (in particular, thermal power) processes prefer to apply elementary formulas for determining the optimal tunings of PI and PID controllers using the controlled plant parameters $[1,3]$. In so doing, they often use the integral of squared control error without taking the control output into account. This approach is quite sufficient for many engineering calculations of the controllers used in automatic control systems (ACSs). However, if a controlled plant is multicapacitive in nature, or if it has explicitly distributed parameters, a simplified mathematical model comprising a firstorder inertial section with time delay can be used for calculating the controller parameters only as a first approximation [2]. At present, many of the proposed methods are based on using nomographic charts. Such an approach gives rise to another error connected with a scatter of the results obtained in using the graphic method by different individuals. The existing functional dependences suggested for calculating the controller parameters are rather cumbersome; the formulas used in them are applicable in a narrow range of parameters, and in many cases the controller parameters are determined with insufficient accuracy.

When operating ACS, utility signals are superimposed on industrial disturbances, which are random disturbances. For these reasons, the output coordinates of the control system almost always represent a random function of time. The description of such systems by means of deterministic approaches is not always justified and does not reproduce the actual picture of the functioning of the ACS. This forces us to move from the traditional deterministic mathematical models of the control system to the stochastic, with all the consequences of the difficult task of the study [5]. Such a complication is especially critical for complex modern control systems, which are described by differential equations of high orders with nonlinearities.

The use of microprocessor automation equipment extends the functionality of the control system and raises the requirements for the quality of its operation. ACS should provide guaranteed quality control in the conditions of random disturbances, as well as minimize the consumption of material and energy resources to achieve the objectives.

The general statistical criterion for the functioning of the ACS is the root mean square error (RMSE) of the useful signal under the conditions of the random interference influence on the plant [5]. The minimum value of RMSE corresponds to optimum conditions of a stochastic ACS functioning. The stochastic control theory main task is the analytic dependencies synthesis that connect the value of the RMSE with the ACS parameters. This allows you to select system parameters that provide a specified or minimal RMSE. The disadvantage of using RMSE as an optimization criterion for a real ACS is that the quality criterion does not take into account the control action minimization and the stabilization accuracy of the task 
Thus, there is a need to adapt the stochastic control theory methods to the industrial automation practical needs, which makes it possible to bring the formalized tasks of synthesizing digital controllers as close as possible to the actual operating conditions of the ACS.

The overwhelming majority of control systems in production are implemented using single-loop ACS, so we consider a linear plant with one input $u$ and one output $y$. The dynamic behaviour of a stationary plant can be represented as a z-transform [4]

$$
y(z)=\frac{B\left(z^{-1}\right)}{A\left(z^{-1}\right)} u(z)
$$

where

$$
B\left(z^{-1}\right)=b_{1} z^{-1}+\ldots+b_{m} z^{-m}, A\left(z^{-1}\right)=1+a_{1} z^{-1}+\ldots+a_{m} z^{-m} .
$$

Suppose that stochastic perturbations affect plants. Since plants are linear, one can use the principle of superposition and apply all disturbances in the form of a single disturbance that acts on the output. In addition, we assume that the perturbations are a stationary Gaussian process with fractional rational spectral density. Thus, in the general case, the model of the interaction of plant with a perturbing medium can be represented by the equation:

$$
y(z)=\frac{B\left(z^{-1}\right)}{A\left(z^{-1}\right)} u(z)+\lambda \frac{D\left(z^{-1}\right)}{C\left(z^{-1}\right)} \gamma(z),
$$

where

$$
D\left(z^{-1}\right)=1+d_{1} z^{-1}+\ldots+d_{m} z^{-m} ; C\left(z^{-1}\right)=1+c_{1} z^{-1}+\ldots+c_{m} z^{-m} ;
$$

$\gamma(z)$ is the uncorrected random signal, and moreover $M\{\gamma(t)\}=\bar{\gamma}(t)=0, \quad M\{\gamma(t) \gamma(t+\tau)\}=\left\{\begin{array}{l}1, \text { if } \tau=0, \\ 0, \text { if } \tau \neq 0 ;\end{array} \quad M \quad\right.$ is the expectation operator. To generalize, in model (2) all the polynomials are of the $m$ order, since the coefficients of higher degrees can always be considered equal to zero.

\section{Formulation of the problem}

In the stochastic control theory, the optimal regulators synthesis is carried out with the assumption that the controller task is set to zero, and the controller parameters are optimized in the perturbation channel to minimize random noise. For industria ACS, it is important to minimize deviations of the output signal plant at the operating point of the task, and it is also necessary to limit the consumption of material resources to achieve the goal. In the article [2] the advanced quality criterion is considered, which takes into account the requirements considered. We use the proposed optimization criterion for the synthesis of stochastic ACS.

Thus, the aim of the work is to synthesize the optimal structure of the digital controller, which ensures the minimum of the quadratic optimality criterion:

$$
J_{t+1}=M\left\{q\left(w_{t}-y_{t+1}\right)^{2}+(1-q)\left(w_{t}-K u_{t}\right)^{2}\right\},
$$

where $w_{t}$ is the reference signal digital controller at $\left[n T_{0}\right] \leq t<\left[(n+1) T_{0}\right], T_{0}$ is the sampling period, $n=0,1,2, \ldots$; $q$ is the weighting factor for the quality criteria of impact ratio imbalance signal $\left(w_{t}-y_{t+1}\right)$ and the reduced control deviations influence $\left(w_{t}-K u_{t}\right), q \in[0 \ldots 1] ; K$ is the plant transfer gain over the control channel, for the static plant $K=\sum_{i=0}^{m} b_{i} / \sum_{i=0}^{m} a_{i}$.

\section{Synthesis of digital controller optimal structure}

The quality criterion (3) uses the variable $y_{t+1}$, not $y_{t}$, because in the initial model (2) $b_{0}=0\left(u_{t}\right.$ control signal does not affect the change in the output value of $y_{t}$ ). We define $y_{t+1}$ as a function of the known variables $y_{t}, y_{t-1}, \ldots ; u_{t}, u_{t-1}, \ldots$. According to equation (2), the predictive value of $y_{t+1}$ can be obtained from the dependence

$$
z y(z)=\frac{B\left(z^{-1}\right)}{A\left(z^{-1}\right)} z u(z)+\lambda \frac{D\left(z^{-1}\right)}{C\left(z^{-1}\right)} z \gamma(z),
$$

where

$$
A\left(z^{-1}\right) C\left(z^{-1}\right) z y(z)=B\left(z^{-1}\right) C\left(z^{-1}\right) z u(z)+\lambda A\left(z^{-1}\right) D\left(z^{-1}\right) z \gamma(z) .
$$

Last equation written in expanded form

$$
\begin{aligned}
& \left(1+a_{1} z^{-1}+\ldots+a_{m} z^{-m}\right)\left(1+c_{1} z^{-1}+\ldots+c_{m} z^{-m}\right) z y(z)= \\
& =\left(b_{1} z^{-1}+\ldots+b_{m} z^{-m}\right)\left(1+c_{1} z^{-1}+\ldots+c_{m} z^{-m}\right) z u(z)+ \\
& \quad+\lambda\left(1+a_{1} z^{-1}+\ldots+a_{m} z^{-m}\right)\left(1+d_{1} z^{-1}+\ldots+d_{m} z^{-m}\right) z \gamma(z) .
\end{aligned}
$$

Having executed multiplication of polynomials and returning to the time domain, we have

$$
\begin{aligned}
y_{t+1}+\left(a_{1}+c_{1}\right) y_{t} & +\ldots+a_{m} c_{m} y_{t-2 m+1}= \\
=b_{1} u_{t} & +\left(b_{2}+b_{1} c_{1}\right) u_{t-1}+\ldots+b_{m} c_{m} u_{t-2 m+1}+ \\
& +\lambda\left[\gamma_{t+1}+\left(a_{1}+d_{1}\right) \gamma_{t}+\ldots+a_{m} d_{m} \gamma_{t-2 m+1}\right] .
\end{aligned}
$$

With (5) we define $y_{t+1}$ and use it in the criterion (3)

$$
\begin{aligned}
J_{t+1} & =M\left\{q \left(w_{t}+\left(a_{1}+c_{1}\right) y_{t}+\ldots+a_{m} c_{m} y_{t-2 m+1}-b_{1} u_{t}-\ldots\right.\right. \\
& \left.\left.-\lambda\left[\left(a_{1}+d_{1}\right) \gamma_{t}+\ldots+a_{m} d_{m} \gamma_{t-2 m+1}\right]-\lambda \gamma_{t+1}\right)^{2}+(1-q)\left(w_{t}-K u_{t}\right)^{2}\right\} .
\end{aligned}
$$

At time $t$, all the variables in (6) are known except for $u_{t}$ and $\gamma_{t+1}$. Perform the expectation operation for (6) given that $\gamma_{t+1}$ does not depend on other variables:

$$
\begin{aligned}
J_{t+1} & =q\left[\left(w_{t}+\left(a_{1}+c_{1}\right) y_{t}+\ldots+a_{m} c_{m} y_{t-2 m+1}-b_{1} u_{t}-\ldots-b_{m} c_{m} u_{t-2 m+1}-\right.\right. \\
& \left.-\lambda\left[\left(a_{1}+d_{1}\right) \gamma_{t}+\ldots+a_{m} d_{m} \gamma_{t-2 m+1}\right]\right)^{2}+\lambda^{2} M\left\{\gamma_{t+}^{2}\right\}- \\
& -2 \lambda\left(w_{t}+\left(a_{1}+b_{1}\right) y_{t}+\ldots+a_{m} b_{m} y_{t-2 m+1}-b_{1} u_{t}-\ldots-b_{m} c_{m} u_{t-2 m+1}-\right. \\
& \left.\left.-\lambda\left[\left(a_{1}+d_{1}\right) \gamma_{t}+\ldots+a_{m} d_{m} \gamma_{t-2 m+1}\right]\right) M\left\{\gamma_{t+1}\right\}\right]+(1-q)\left(w_{t}-K u_{t}\right)^{2} .
\end{aligned}
$$

The optimal value of the control signal $u_{t}$ we define conditions

$$
\begin{aligned}
& \frac{\partial J_{t+1}}{\partial u_{t}}=q\left(w_{t}+\left(a_{1}+c_{1}\right) y_{t}+\ldots+a_{m} c_{m} y_{t-2 m+1}-b_{1} u_{t}-\ldots\right. \\
& \left.\quad-\lambda\left[\left(a_{1}+d_{1}\right) \gamma_{t}+\ldots+a_{m} d_{m} \gamma_{t-2 m+1}\right]\right) b_{1}+K(1-q)\left(w_{t}-K u_{t}\right)=0 .
\end{aligned}
$$

With (5) we define

$$
\begin{aligned}
y_{t+1}-\lambda \gamma_{t+1}= & -\left(a_{1}+c_{1}\right) y_{t}-\ldots-a_{m} c_{m} y_{t-2 m+1}+b_{1} u_{t}+\ldots \\
& +\lambda\left[\left(a_{1}+d_{1}\right) \gamma_{t}+\ldots+a_{m} d_{m} \gamma_{t-2 m+1}\right] .
\end{aligned}
$$

Using (8) into (7), we have

$$
\frac{\partial J_{t+1}}{\partial u_{t}}=q\left(w_{t}-y_{t+1}+\lambda \gamma_{t+1}\right) b_{1}+K(1-q)\left(w_{t}-K u_{t}\right)=0
$$

The difference equation (9) is represented as a z-transform

$$
q(w(z)-z y(z)+\lambda z \gamma(z)) b_{1}+K(1-q)(w(z)-K u(z))=0 .
$$

With (4) we find $\lambda z \gamma(z)=\frac{C\left(z^{-1}\right)}{D\left(z^{-1}\right)} z y(z)-\frac{B\left(z^{-1}\right) C\left(z^{-1}\right)}{A\left(z^{-1}\right) D\left(z^{-1}\right)} z u(z)$

Use it in (10) and get

$$
\begin{aligned}
q\left(w(z)-z y(z)+\frac{C\left(z^{-1}\right)}{D\left(z^{-1}\right)} z y(z)\right. & \left.-\frac{B\left(z^{-1}\right) C\left(z^{-1}\right)}{A\left(z^{-1}\right) D\left(z^{-1}\right)} z u(z)\right) b_{1}+ \\
& +K(1-q)(w(z)-K u(z))=0 .
\end{aligned}
$$

For the last expression, we perform mathematical transformations and obtain the optimal digital controller equation with the minimum dispersion:

$$
u(z)=L\left(z^{-1}\right)\left[H\left(z^{-1}\right) w(z)-F\left(z^{-1}\right) y(z)\right],
$$

where

$$
\begin{gathered}
L\left(z^{-1}\right)=\frac{A\left(z^{-1}\right)}{K^{2}(1-q) A\left(z^{-1}\right) D\left(z^{-1}\right)+q b_{1} B\left(z^{-1}\right) C\left(z^{-1}\right) z} ; \\
H\left(z^{-1}\right)=\left(q b_{1}+K(1-q)\right) D\left(z^{-1}\right) ; F\left(z^{-1}\right)=q b_{1}\left(D\left(z^{-1}\right)-C\left(z^{-1}\right)\right) z
\end{gathered}
$$


For $A\left(z^{-1}\right)=C\left(z^{-1}\right)$ and/or $q=1$ we have separate cases of the digital controller implementation:

1) if $A\left(z^{-1}\right)=C\left(z^{-1}\right)$, then

$$
\begin{aligned}
& L\left(z^{-1}\right)=\frac{1}{K^{2}(1-q) D\left(z^{-1}\right)+q b_{1} B\left(z^{-1}\right) z}, \\
& H\left(z^{-1}\right)=\left(q b_{1}+K(1-q)\right) D\left(z^{-1}\right) \\
& F\left(z^{-1}\right)=q b_{1}\left(D\left(z^{-1}\right)-C\left(z^{-1}\right)\right) z
\end{aligned}
$$

2) if $q=1$, then $L\left(z^{-1}\right)=\frac{A\left(z^{-1}\right)}{b_{1} B\left(z^{-1}\right) C\left(z^{-1}\right) z}$,

$$
H\left(z^{-1}\right)=b_{1} D\left(z^{-1}\right), F\left(z^{-1}\right)=b_{1}\left(D\left(z^{-1}\right)-C\left(z^{-1}\right)\right) z ;
$$

3) if $q=1$ and $A\left(z^{-1}\right)=C\left(z^{-1}\right)$, then $L\left(z^{-1}\right)=\frac{1}{b_{1} B\left(z^{-1}\right) z}$,

$$
H\left(z^{-1}\right)=b_{1}, F\left(z^{-1}\right)=b_{1}\left(D\left(z^{-1}\right)-C\left(z^{-1}\right)\right) z \text {. }
$$

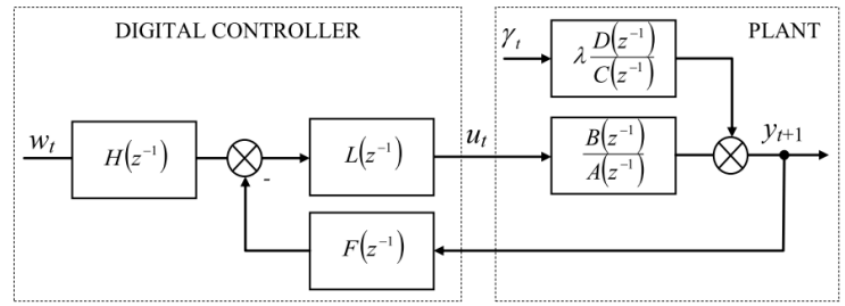

Fig. 1. Block diagram of stochastic ACS

The block diagram of the synthesized control system, including the plant (4) and digital controller (11), is shown in Fig. ${ }^{\circ}$. The resulting structure of the optimal digital controller for a stochastic one-dimensional plant corresponds to the generalized structure of a linear digital controller [8].

The law of optimal control (11) determines the control action and minimizes the quality function at the operating point of the set point $w_{t}$ of the control system for each quantization period. As a result, over time, the dispersion of the generalized quality function (3) is minimized.

\section{An example of the digital controller synthesis}

Consider an example of the optimal digital controller synthesis to stabilize the temperature at the output of the ceiling air conditioner CV-P 2L N-63B/F-N manufactured by VTS CLIMA [7]. In [6], a dynamic model of a water heat exchanger is considered on the example of the CVP2-HW2 heater, which is used in the CV-P 2L N-63B/F-N conditioner. For this heater, the parameters of the mathematical model are determined by channels: control $W_{1}(p)=\frac{0.44}{0.6 p^{3}+6.4 p^{2}+6.9 p+1}$; disturbances $W_{2}(p)=\frac{1.4 p^{2}+2.8 p+0.56}{0.6 p^{3}+6.4 p^{2}+6.9 p+1}$. The heater CVP2-HW2 is used in the circuit for stabilizing the temperature at the outlet of the air conditioner in the winter mode of the microclimate system. In this case, with sufficient accuracy, we can assume that the temperature perturbations of the environment are uncorrelated random disturbances with zero expectation.

The quadratic quality criterion (3), which must be minimized during the digital controller synthesis, is

$$
J_{t+1}=M\left\{0.999\left(w_{t}-y_{t+1}\right)^{2}+0.001\left(w_{t}-0.44 u_{t}\right)^{2}\right\} .
$$

When synthesizing a digital controller, we take into account the inertia of the actuator $W_{a c t}(p)=\frac{1}{10 p+1}$ and the temperature sensor $W_{s}(p)=\frac{1}{14 p+1}$, that is $W_{p}^{w \rightarrow y}(p)=W_{a c t}(p) W_{1}(p) W_{s}(p)$;
$W_{p}^{\gamma \rightarrow y}(p)=W_{2}(p) W_{s}(p)$. Thus, the mathematical model of the plant by channels:

$$
\begin{gathered}
W_{p}^{w \rightarrow y}=\frac{0.44}{84 p^{5}+910 p^{4}+1120 p^{3}+312 p^{2}+31 p+1} ; \\
W_{p}^{\gamma \rightarrow y}=\frac{1.4 p^{2}+2.8 p+0.55}{8.4 p^{4}+90 p^{3}+103 p^{2}+21 p+1} .
\end{gathered}
$$

The dynamics of the water heater, which is described by the transfer functions (13) and (14), will be represented using the discrete model (2) with the sampling period $T_{0}=2$ :

$$
\begin{aligned}
y(z)= & \frac{0.00017 z^{-1}+0.00148 z^{-2}+0.00121 z^{-3}}{1-2.434 z^{-1}+1.975 z^{-2}-0.535 z^{-3}} u(z)+ \\
& +0.0465 \frac{1-0.4769 z^{-1}-0.1022 z^{-2}}{1-1.674 z^{-1}+0.772 z^{-2}-0.063 z^{-3}} \gamma(z) .
\end{aligned}
$$

We use (15) to determine the polynomials of the digital controller, which includes (11):

$$
\begin{gathered}
L\left(z^{-1}\right)=\frac{1-2.434 z^{-1}+1.975 z^{-2}-0.535 z^{-3}}{0.1936-0.5633 z^{-1}+0.5872 z^{-2}-0.238 z^{-3}+0.0105 z^{-4}+0.0106 z^{-5}} ; \\
H\left(z^{-1}\right)=0.6098-0.2908 z^{-1}-0.0623 z^{-2} \\
F\left(z^{-1}\right)=0.2033-0.1485 z^{-1}+0.0107 z^{-2}
\end{gathered}
$$

With help of MatLAB Simulink software package we will carry out simulation modelling of the synthesized ACS. The block diagram of the control system that was modelled is shown in fig. 2. Fig. 3 shows the transient processes of the stochastic ACS, which minimizes the variance of the air temperature deviation at the outlet of the CV-P 2L N-63B / F-N conditioner for the winter control system operation. The random process was modelled by a sequence of normal random variables with parameters $(-0.5,0.5)$.

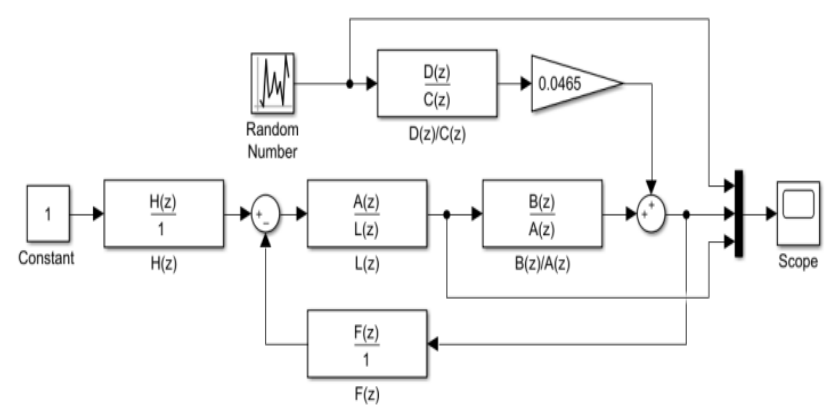

Fig. 2. Block diagram of ACS for modeling in Simulink

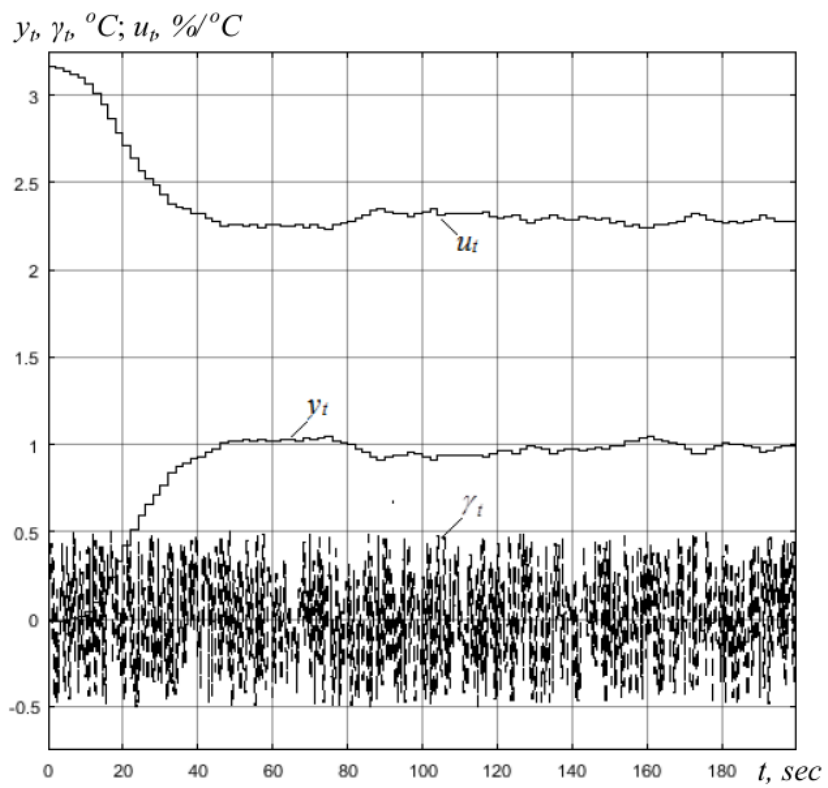

Fig. 3. Transients stochastic ACS 
As it can be seen from fig. 3 digital controller ACS well compensates random noise with parameters $(-0.5,0.5)$. Despite the considerable amplitude of the random signal, the digital controller of the control system stabilizes the output value $y_{t}$ with a slight drift around the $w_{t}$ reference.

\section{Conclusions}

The article describes the synthesis of optimal stochastic digital ACS. The quality criterion (3) is adapted to the control real problem processes, which allows to minimize the error variance of the output signal of a plant from the reference signal of ACS. The structure of the digital controller was analysed depending on the parameter $q$ of the quality criterion and the mathematical description of the plant (2). An example of the digital controller synthesis for a control system with air temperature at the ceiling conditioner output CV-P 2L N-63B/F-N, which showed the efficiency of the digital controller for compensating stochastic disturbances, is given. The digital controller mathematical dependence (11) is recommended for use in the automation of production processes.

\section{Ph.D. Igor Golinko}

e-mail: conis@ukr.net

Associate Professor of the sub-department of Automation Heat-and-Power Engineering processes of Heat-and-Power Engineering department, National Technical University of Ukraine "Igor Sikorsky Kyiv Polytechnic Institute", Kyiv, Ukraine.

Author of over 100 scientific papers. Engaged in scientific mathematical simulation of technical and technological processes, computer techniques and computer technologies, programming.

\section{References}

[1] Golinko I.M., Kovrigo Yu.M., Kubrak A.I.: An Express Method for Optimally Tuning an Analog Controller with Respect to Integral Quality Criteria. Thermal Engineering 3(61)/2014, 189-197.

[2] Golinko I. M.: Optimal Tuning of a Control System for a Second-Order Plant with Time Delay, Thermal Engineering 7(61)/2014, 524-532.

[3] O'Dwyer A.: Handbook of PI and PID controller tuning rules. Imperial College Press, London, 2009

[4] Rabbath C.A., Léchevin N.: Discrete-Time Control System Design with Applications. Springer-Verlag, London, 2014.

[5] Afanas'yev V.N.: Stokhasticheskiye sistemy. Otsenki i upravleniye. Editorial URSS, Moscow, 2018.

[6] Holinko I.M., Halyts'ka I.Y.E.: Dynamichna model' teploobminu dlya vodyanoho kaloryfera u prostori staniv. Informatsiyni systemy, mekhanika ta keruvannya 15, 2016, 83-92.

[7] Katalog. VENTUS - ventilyatsionnyye agregaty i tsentral'nyye konditsionery. VTSGroup, Moscow 2003.

[8] Romanenko V.D.: Metody avtomatyzatsiyi prohresyvnykh tekhnolohiy Vyshcha shk., Kyyiv 1995.

\section{D.Sc. (Technical) Volodymyr Drevetskiy}

e-mail:Westra@rv.uar.net

Vice President of Engineering Academy of Ukraine, Head of Automation, electrical engineering and computer integrated technologies Department, National University of Water Management and Nature Resources Use, Rivne, Ukraine.

The main scientific direction - development of methods and devices for continuous automatic monitoring of the physical and mechanical parameters of Newtonian and non-Newtonian fluids, as well as the quality of oil products. Author of over 200 scientific papers, including 51 patents, most of which are implemented in production.

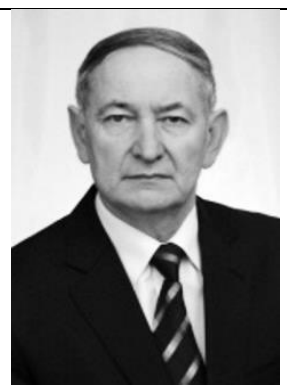

ORCID ID: 0000-0001-8999-2226 